\title{
The Role of State, Non-State Actors and Information Communication Technologies in Peace-Building in Mt. Elgon Region, Kenya
}

\author{
Joseph Osodo ${ }^{1}$ \\ Israel Kibirige ${ }^{1}$ \\ Cherotich Mung'ou² \\ 1 University of Limpopo, Polokwane, South Africa. E-mail: Israel.Kibirige@ul.ac.za \\ 2Kabarak University, Nakuru, Kenya
}

\section{Doi:10.5901/mjss.2014.v5n3p358}

\section{Abstract}

Intra-state conflicts in the African continent pose a threat to stability and security of the region. The conflict pitting Soy and Ndorobo clans in Mt. Elgon erupted when members of the Soy clan rejected an attempt by the government of Kenya (GoK) to resettle the landless members of the Ndorobo in Chebyuk settlement scheme. The conflict had great socio-economic impacts like loss of lives, massive destruction of property, population displacement and feelings of hatred and animosity amongst the residents. While there is a plethora of literature on causes and effects of intra-ethnic conflicts in Kenya, there is a dearth on peace-building endeavours and the potential of Information Communication Technologies (ICTS) in conflict resolutions. This study was designed to assess the potential role of state, non-state actors and ICTs in peace-building. The study was based on the conflict transformation theory and diffusion of innovations theory. This qualitative study used in-depth interviews using local inhabitants, state and non-state actors purposively sampled. Data were analysed based on the interpretive approach. The results show that ICTs such as mobile telephones, the Internet and radio-phones had a great potential in peace-building but were seldom (20\%) employed. The paper contributes to the on-going dialogue on peace building efforts in Mt. Elgon and other regions experiencing similar conflicts and recommends more use of ICTs in peace-building efforts than was the case in this study.

Keywords: ICTs, Peace-building, State Actors, Non-state Actors

\section{Introduction}

Since the end of the cold war, the international community has turned its attention anew to violent intra-state conflicts and humanitarian crises stretching across various countries, regions and continents (Islam \& Chakma, 2013; Welling, 2007). The wave of conflicts ushered in by the post-cold war period has led to various approaches by stakeholders including state and non-state actors aimed at ensuring sustainable peace and security. Conflicts have various effects on individuals and society at large (Cilliers \& Schuenemann, 2013). These effects include loss of lives, evictions and displacements, destruction of infrastructure, loss of property and psychological trauma on the affected individuals, especially due to torture and disappearances of family members. Non-governmental organizations (NGOs), both national and international, are particularly playing an important role in conflict intervention and post-conflict peace-building (Uzuegbunam, 2013). The International Non-Governmental Organizations (INGOS), the Community Based Organizations (CBOs) and religious bodies are engaged in semi-formal conflict management at grassroots level. These non-state actors employ various conflict management approaches ranging from non-official facilitation, mediation and problemsolving workshops to the use of civilian peace monitors, non-violent campaigns and cultural exchanges (Abdulrahman \& Tar, 2008; Cheldelin et al., 2003). On the other hand, the state employs official diplomacy tasks ranging from negotiation, conciliation and mediation to other formal activities geared towards structurally peaceful social systems characterised by economic, political and cultural systems in which decision-making power is equitably distributed (Cheldelin et al., 2003). Most NGOs, like the International Committee of Red Cross (ICRC), Save the Children, Oxfam, the Mennonite Central Committee and the Brethren Service Committee concentrate their efforts between development and war prevention as well as economic and social rehabilitation of war-torn societies (Cheldelin et al., 2003).

External interventions have always been sought in situations where states are unable to secure the interests of the minority. A majority of these interventions are mediated by the United Nations (UN). An example of such interventions 
was during the cross border dispute between Cameroon and Nigeria over the Bakassi Peninsula (Quinn et al., 2013; Anyu, 2007). The effectiveness of international bodies like the UN, International Monetary Fund (IMF) and World Bank as democratic institutions is being eroded since they represent the interests of global powers. For instance, the UN allowed Israel and the Democratic Republic of Congo to defy Security Council resolutions because of their alliance with the west while it mercilessly enforced resolutions against Libya, Sudan and Iraq (Okoth \& Ogot, 2009). It is worth noting that successful peace-making entails supporting local negotiations rather than prescribing outcomes based on western contexts. International actors often employ the top-down approach which hinders meaningful peace realization due to its non-inclusiveness (Babaud \& Ndung'u, 2012; Boaduo, 2010).

The African continent created bodies for establishing peace and security in the region, notably the Organization of African Union (OAU), now known as the African Union (AU) to carry out peace-making and peace-building activities in war-torn countries like Sudan. The AU was successful in restoring peace in Kenya following the 2007/2008 post-election violence (PEV) where the East African Community had failed (GoK, 2012). The AU has been participating in peacekeeping missions in many African countries in a bid to stabilize such countries. However, they have not been able to end the conflicts in Sudan, Congo and Northern Uganda. The inability of AU forces to end conflicts is attributed to lack of skilled manpower and finances to sustain long wars and the AU's principle of non-interference in the internal affairs of member states that prevents intervention in conflict situations (GoK, 2012). This has often been criticized by the NGOs as a state-centred approach to conflicts as opposed to a holistic approach to conflict management. Other regional organizations include the Inter-Governmental Authority for Development (IGAD) which was successful in negotiating for the cessation of Southern Sudan from Northern Sudan. The major impediment to the negotiations of these organizations stems from the struggle for regional supremacy among the African presidents which has led to the emergence of subregional hegemonies that have come to dominate these organizations. For instance, the Economic Community of West African States (ECOWAS) anchors around Nigeria, the Southern African Development Community (SADC) on South Africa while the Inter-Governmental Agency on Development (IGAD) and the East African Community (EAC) anchors around Kenya. Subsequently, this makes the organizations negotiate conflicts to the benefit of these countries (Cilliers \& Schuenemann, 2013).

\section{Statement of the Problem}

Although Kenya is considered to be more peaceful than her neighbours, a close scrutiny reveals an unprecedented wave of internal and cross-border conflicts. These conflicts mainly manifest themselves as political, economic, environmental, conflicts over natural resources, land and tribal clashes, and lately, terrorism. Pastoralists in northern Kenya have borne much of the brunt of internal conflicts and considerable efforts have been directed at addressing these by a number of stakeholders including Government of Kenya (GoK), Civil Society Organizations (CSOs), religious organizations and community-based organizations (CBOs) (GoK, 2012). The resource-based conflicts prevalent in Arid and Semi-Arid Lands (ASALs) have distorted development programmes and eroded civil administration of this vast and rugged countryside. For example, the formal and informal conflict resolution mechanisms existing in Mt. Elgon are inadequate and concentrated in a few areas of the region like Kopsiro and Cheptais without catering for the displaced civilians who are in other parts of the region. This raises a question on the supposed all-inclusive conflict management mechanisms. Fati (2010) examined the impact of Information Communication Technologies (ICTs) on conflict management in the Niger Delta and concluded that ICT is crucial in facilitating participatory dispute resolution. Likewise, it was noted that mobile phone technology like short text messages (SMS) and mobile banking (Wilson \& Wilson, 2009), social network platforms (Comninos, 2013) like the internet and satellite technology among others, can be used in peace-building efforts. This study therefore seeks to investigate the role of governmental and non-governmental actors in peace building as well as the potential use of ICTs as an alternative dispute resolution mechanism.

\section{Objectives of the Study}

The objectives of the study were to:

1) analyze the effectiveness of peace process initiatives by state and non-state actors in Mt. Elgon region and;

2) assess the potential role of ICTs in peace-building in Mt. Elgon region conflict. 


\section{Theoretical Framework}

The study was based on the conflict transformation theory and diffusion of innovations theory in relation to adoption of new technologies. Berghof Foundation (2012) refers to conflict transformation as a generic, comprehensive term referring to actions and processes seeking to alter the various characteristics and manifestations of violent conflict by addressing the root causes of a particular conflict over a long term. Conflict transformation theory aims at transforming negative conflict into constructive conflict, deals with structural, behavioural and attitudinal aspects of conflict. The term refers to both the process and the means of the process. As such, it incorporates activities such as conflict prevention and conflict transformation. The conflict transformation theory, as adopted in this study refers to engagements that change various features and indices of ferocious conflicts as it addresses the root causes of conflicts over a long term. In this study, it was used as a process where intra-clan conflicts were transformed into peaceful outcomes. Thus, it is a process of engaging with and transforming the relationships, interests, discourses and, if necessary, the constitution of society that supports the continuation of violent conflict (Berghof Foundation, 2012; Kaminski, 2011; Dearing, 2009). Since there were perennial inter-clan conflicts in Mt. Elgon area emanating from perceived bias in resource allocation and unpopular intervention measures by the government, the conflict transformation theory was therefore deemed relevant in this study.

Diffusion of innovations theory, on the other hand, seeks to explain how, why and the rate at which new ideas, through technology, spread within and among different social systems. According to Rogers (1995: 409), diffusion of innovations refers to:

\footnotetext{
"...the process by which an innovation is communicated through certain channels over time among the members of a social system. An Innovation is an idea, practice or object perceived as new by an individual or other unit of adoption. The diffusion of innovations involves both mass media and interpersonal communication channels...."
}

By sharing communication channels such as interpersonal communication or mass communication, people can get information of an innovation and perceive it as useful (Dearing, 2009; Greenhalgh et al., 2004; Rogers, 2003). Diffusion research has attempted to explain the variables that influence how and why users adopt a new information medium, such as the Internet. Interpersonal influences are deemed important since the individual is usually the unit of analysis. Critical mass also becomes an important factor in adopting new media as they are interactive tools and thus are required by many users to gain efficiency. That is, the more people use ICTs, the more they get benefits. In this sense, diffusion theory not only applies to practical things, but is also related to the digital divide (Rogers, 2003). Since communication technologies during the information age are imperative in daily life, this theory was useful in determining the prevalence and efficacy of ICTs use in peace-building endeavours.

\section{Participants}

This study used purposive sampling to select the participants (Creswell, 2007). Certain criteria were used to ensure that the respondents could resolutely inform and contribute to the issues raised. The main criterion here was that they must have witnessed the conflict or had experience dealing with the affected group. As a result, the researchers were able to optimize sampling diversity and address emergent perspectives. The participants consisted of 8 District Peace Committee (DPC) members, 10 women representatives, 8 youth, 5 ex-militia, 5 elders, 8 CSOs and 6 provincial security officers.

\section{Data Collection and Analysis}

A qualitative approach, based on the interpretive approach, was used as it allowed the researchers to gain valuable insights into the salient issues under consideration. A qualitative approach is considered appropriate when little is known about an issue and when the topic is emotive and sensitive; as was the case in this study (Creswell, 2007). The interpretive approach was deemed necessary as it would provide insights into meaning making experiences and perspectives of the participants (McGill-Franzen \& Allington, 2011). It was believed that through narrations of respondents' points of view, the researchers could gain insight and identify salient issues (Bryan \& Burgress, 1999). Data were collected using in-depth interviews. Prior to the interviews, the participants were approached and informed of the purpose of the study and their informed consent sought and all consented. The interviews were then administered in a flexible order, at places and times of their convenience. During the interviews which lasted about 50 minutes, the researchers observed confidentiality and avoided distractions and interruptions. The interview schedule catered for 
follow-up questions to further probe response. The researcher ensured that the respondents understood the questions. The questions were rephrased as a probing technique in order to ascertain consistency of the responses. For credibility, the respondents read transcripts to ascertain if their views were captured correctly. Any area of disagreement was debated upon to build consensus. Field notes were also taken for further reflection and corroboration.

\section{Results and Discussions}

Results are presented and discussed in three main areas namely: state actors, non-state actors and ICTs in peacebuilding processes. Many respondents had similar experiences and as such direct quotations are minimal in this report. The few presented capture and summarize the key findings.

\subsection{State and non-state actors}

Both state and non-state actors were involved in the Mt. Elgon conflict. The non-state actors included the Sabaot Land Defense Force (SLDF) and other criminal gangs who benefitted from the ensuing chaos such as the Moorland Defense Force (MDF) and the Political Revenge Movement (PRM). These militia groups terrorized the residents, leading to loss of lives and property, displacement and mistrust between the communities which had coexisted peacefully (Baumann, 2011; Simiyu, 2010). For instance, a respondent observed what she had witnessed:
"...At around 5pm, my neighbour was at home when some men came to her compound. They asked for her husband, but he was not at home. They demanded to know how many of the SLDF she knew, since they alleged that she went round talking about them. She declined and they kidnapped her and took her to an unknown place. There, they blind- folded her, raped her in turns and even beat her for almost 24 hours. The following day she was unconscious, but they did not let her go. She was told to open her mouth where one of them urinated...".

This was an evidence of the extent of traumatic experiences the victims underwent, yet there were state and nonstate actors. Another participant said:

\footnotetext{
"...After a thorough beating, they left her, but she was nearly unable to walk home because of the pain she had. She forced herself up because she believed that if she continued to stay there, others might come and continue the torture. She tried, and thankfully, a person helped her home. Probably if she had a mobile telephone, she would have solicited for and got assistance in time...."
}

These were clear testimonies of governmental agencies' ineptitude in responding to the security concerns of the inhabitants, leaving them at the mercy of militia groups. It was also evident that the victims would have been able to get help had she got a robust means of communication such a cellular telephone.

The state as an actor was involved in the resettlement plans in the scheme from the early 1970s but all the resettlement plans were never fully implemented leading to the Chebyuk I (1971-1974), Chebyuk II (1989-1994 and Chebyuk III (1993-2006), all of which were marred by allegations of corruption and subsequent nullifications of the resettlement programmes (TJRC, 2013). Furthermore, the resettlement programmes led to tension between the Soy and the Ndorobo clans due to political interference in the whole resettlement process as the land issue was used as political bait during campaigns. Again, the state has been blamed for the delayed issuance of title deeds and allotment letters for the intended beneficiaries (KNCHR, 2008).

According to Mwasserah (2007), peace meetings amongst the amongst the conflicting clans were held, culminating in the meeting attended by over 430 leaders from both clans. In addition, several meetings were held between the provincial security intelligence committee (PSIC), former members of parliament from Mt Elgon and councilors to scrutinize the list of beneficiaries of Chebyuk III. Attempts by the provincial administration to hold meetings with the leaders from the two clans yielded no fruit and this contributed to the continued conflict in the region due to the revered position accorded to them in the Sabaot culture. In addition, the leaders ('laibons') were often accused of administering oaths to the youth (Kamoet, 2007; Simiyu, 2008). In a disarmament effort, a meeting was held with all chiefs, District Officers (DOs), District Security Intelligence Committee (DSIC) and the Provincial Security Intelligence Committee (PSIC) where an amnesty for surrender of arms was declared. The surrender points were identified as Kipsigon, Masaek and Cheptais. In addition, a cash reward of $\$ 120$ was promised for any weapon and ammunition that was surrendered to the police. However, by the expiry of the deadline, not a single weapon or ammunition had been handed in. This posed a threat to lasting peace in the region as many guns were still in the hands of the local residents 
(Mwasserah, 2007; Simiyu, 2008).

The state's response to the conflict was localized to the chiefs who were tasked with the responsibility of ensuring peace in their areas of jurisdiction. Subsequently, curfews were put in place, to be enforced by the chiefs and administration police. In addition, several police patrol bases and posts were opened to beef up security in the area. The state also deployed more security personnel, including special units such as the Rapid Deployment Unit, Anti-Stock Theft Unit and the paramilitary General Service Unit. However, these approaches failed and the SLDF continued to spread terror and commit atrocities in Mt. Elgon and in parts of Trans-Nzoia District (KNCHR, 2008; Simiyu, 2008; Mwasserah, 2007). The escalation of the conflict forced the state to deploy the military in March, 2008 to deal with the SLDF menace. The army set up a base at Kapkota in Sasur location of Cheptais District and launched its operations, christened Operation Okoa Maisha ('Operation Save Life'). Military intervention was marred with human rights abuses including arbitrary arrests, detentions, killings, disappearances, torture at military bases, destruction of property and massive displacement of residents (Simiyu, 2008; HRW, 2008; KNHCR, 2008).

In an effort to bring healing and reconciliation in the region, the Truth, Justice and Reconciliation Commission (TJRC) visited Mt. Elgon and organized for truth hearing sessions from victims and perpetrators of violence. The commission provided victims, perpetrators and the general public with a platform for non-retributive truth-telling aimed at bringing justice to the victims. However, truth commissions only engage in uncovering crimes and issuing final reports that function as official histories of what actually happened but they do not offer justice to the victims of the violence. Hence, truth commissions are less likely to bring justice. According to Moore (2011), truth commissions do not corroborate facts; cross-examine witnesses or judge individuals' guilt. The final report of the TJRC is yet to be received by the government and justice is yet to be accorded to the affected.

According to National Cohesion and Integration Commission (NCIC) (2012), non- state efforts at peace-building are often undertaken by local, national and international NGOs and INGOs as well as CBOs. CSOs' efforts are geared towards conflict management across the country and more particularly in marginalized rural and pastoralist areas (Simiyu, 2008; KNHCR, 2008). Since the early 1990s, the CSOs have played a central role in facilitating and implementing conflict management and peace-building strategies. These non-state actors constituted a peace-building sub-theme, which played a pivotal role in opening up the society and in overall development. The activities of these actors are, however, more peace-time oriented than focused on issues of crisis and conflict. On the onset of the SLDF violence, Mwatikho Torture Survivors Organization (MATESO), a human rights organization and International Rehabilitation Council for Torture Victims (IRCT) in Kenya, were at the forefront in documenting the cases in Mt. Elgon and treating the victims of torture, besides offering psychological counseling. In June 2008, jointly with Independent Medico-Legal Unit (IMLU) center, MATESO documented, treated and counseled 250 torture cases from the Mt. Elgon military operation (Simiyu, 2008; HRW, 2008; KNHCR, 2008). Mt. Elgon Residents Association (MERA), in conjunction with the Kenya Red Cross Society (KRCS), organized sports (Mt. Elgon Peace Run and Football) in February 2009 and February, 2012 bringing together all the clans in a bid to reconcile them and bring lasting peace in the region. The events were successful in drawing participants and spectators from both clans and other minor communities in the region. These events were used to sensitize the communities on peace and sustainability in the region. In addition, the KRCS society has been engaged in tracing the missing persons in order to restore family links within the community following disappearances due to SLDF and military operations. The society recorded success in the exercise since many families were reunited. The KRCS initiated cash for work programme from 2008-2013 in the areas that were adversely affected by the conflict. This entailed construction of roads joining two communities in a bid to bring peace in the region (Simiyu, 2008; HRW, 2008; KNHCR, 2008). In 2013 KRCS society initiated projects in schools and health facilities in order to attain long term solutions to conflict, which required the emergency preparedness and response (EPR) unit. These projects were meant to disengage people from conflict and encourage them towards development activities.

The Afrika Study Centre (ASC) with its theme of 'cross-border people to people reconciliation and restorative programme' aimed at creating space for restorative peace in Mt. Elgon region. With the support of Cross-cultural Foundation Uganda (CCFU), they organized six negotiations aimed at addressing the issues confronting widows in the society (Wanda, 2013). The first discussion took place on 1'st May, 2013 at the Marcus Garvey University, upper Mooni campus, in Mbale, Uganda. It brought together widows and women from around Mt. Elgon region. Most of the widows were drawn from Cheptais District since they were adversely affected by the SLDF and military operations. The discussion provided psychological healing to the widows as they were able to share the challenges they face in the community. MERA also organized a peace tour for the ex-SLDF members, SLDF widows, and leaders to Lira, Uganda to witness the atrocities inflicted on civilians by the Lord Resistance Army (LRA). In addition, widows of former SLDF members formed the ambassadors of peace movement comprising over 500 women mainly focused on agricultural 
activities and preaching peace in the region. However, these ambassadors lack a forum for preaching peace to the rest of the community. More so, the widows have been involved in frequent fights and quarrels amongst themselves, making the realization of peace elusive (Simiyu, 2008; HRW, 2008; KNHCR, 2008).

The National Steering Committee on Peace building and Conflict Management (NSC), through the support of Act Kenya, organized a Mt. Elgon leaders' consultative meeting in February 2011 attended by the then MP and two former MPs. This culminated in the formation of the DPCs in Cheptais and Mt. Elgon districts in Bungoma County. The DPCs have been conducting various peace-building initiatives in the region like the Cheptais-Sirisia boundary meeting held in April, 2013, aimed at ending the conflicts between the Sabaot and Bukusu experienced every electioneering year. For example, the 1992/1997 ethnic clashes witnessed in the region led to a strained relationship between the two communities. In addition, a joint water project was initiated to encourage peaceful coexistence between the two communities (Simiyu, 2008; HRW, 2008; KNHCR, 2008). Intra-community meetings facilitated by MERA, which has been involved in peace efforts and mediation, led to intra-community discussions culminating in the Mabanga Peace Conference. The community elders, political leaders, religious leaders, government officials and other stakeholders held the first-ever meeting comprising the six Sabaot clans between 22nd and 28 Training College (ATC) in Bungoma. The conference paved way for subsequent discussions between the Soy and Ndorobo clans. A community meeting between the Soy and Ndorobo elders was held on 16 ${ }^{\text {th }}$ August, 2011 to address issues leading to conflicts between the two clans. The discussion enabled the communities to open up and discuss causes of conflicts between the two communities (GoK, 2012; HRW, 2008). For instance, the Mosop cited discrimination in the allocation of CDF funds since the former area MP hailed from the Soy clan. Other issues included noninclusiveness of the CBOs from the groups by NGOs like PACT Kenya and FPFK. The Peace Rights Programme (PRP) also supports inter-community discussion meetings as a follow-up activity after the Mabanga Conference in an effort to reconcile the Sabaot, Teso and the Bukusu, who have been involved in conflicts over natural resources as demonstrated by the 1992/1997 ethnic clashes between the Sabaot and minority tribes. It is, however, difficult to attain peace among these three communities since the land conflict in Mt. Elgon has not yet been resolved (Wanda, 2013).

The Sabaot International Cultural Day, which brought together all communities within the Elgon Region in Kenya and Uganda, was organized for the first time in 2010 at Cheptais High School, Kenya by MERA and Teso peace and human rights development initiative. The choice of the venue was important since it was the most affected area, especially since the military operation was centered in Cheptais District (GoK, 2012; HRW, 2008). The cultural day brought together communities which had undergone similar conflicts in the regions around Mt. Elgon and across the Ugandan border. A similar event was organized in November 2012 at Kapchorwa in Uganda. The event brought together communities which had a history of conflicts. These were the Teso from Uganda and Kenya; the Bukusu from Kenya and Bagisu (Bamasaba) from Uganda; the Pokot from Kenya and Uganda; the Sabaot from Kenya and the Sebei from Kenya and Uganda. The two cultural events were used to preach peace among the different communities and to promote cultural understanding among cross-border communities.

Across the Mt. Elgon region, efforts to rehabilitate the ex-militia boys are on-going. These include the USAID Pact funded and Act implemented, Kenyan Civil Society Strengthening Program (KCSSP) and Mt. Elgon Integrated Peace and Development project (Simiyu, 2008; HRW, 2008). These efforts are viewed as a reckoning force to reintegrate the youth and promote reconciliation and community cohesion. Mt. Elgon Peace Initiative (MEPI), Vijana Umoja Pamoja (VUP) and Amani CBO are the guarantees expected to transform the lives of the youth in the region through their wellcrafted interventions: songs, theatrical performances and providing civic education to the community in order for them to access justice in addressing human rights abuses. Peace and Rights Programme (PRP) started in 2009 by the Free Pentecostal Fellowship in Kenya (FPFK) engaged in various peace building activities and promotion of human and community rights. Examples of these activities include reintegration of SLDF ex-combatants into the community. This, however, is impeded by inadequacy of skills to support livelihoods. Other interventions have been organized by faithbased organizations (FBOs). For instance, in 2008, the Oxfam and the Pastor's Forum organized a pulpit exchange programme bringing together religious leaders form the warring clans in order to preach peace and reconciliation among the community members. The CSO network in conjunction with PACT Kenya and DPC, held a consultative national peace policy that brought together 50 people per division in Kapsokwony on 26 th $A$ Aug 2011.

The INGOs have also been supporting peace-building initiatives in the region. For instance, Saferworld supported the Mt. Elgon DPC and the Provincial Administration to hold peace consultations in Kopsiro and Chaptais divisions of Mt. Elgon in order to initiate a process of peace consultations at the grassroots level with various actors in the district. The forums brought together government representatives, members of the community from various locations, Mt. Elgon DPC, internally displaced persons' (IDPs) representatives, and humanitarian and development agencies working in the area 
(Saferworld, 2010). Saferworld and its partners (PeaceNet and the Catholic Justice and Peace Commission) have made steps to bring women on board in peace initiatives and in December 2011, it supported the Mt. Elgon DPC to hold a peace forum that brought together women from various divisions of Mt. Elgon District. The forum aimed to get women's perspectives of peace and security in Mt. Elgon and to stimulate debate on the need for them to actively participate in peace-building and conflict transformation by developing women-specific peace initiatives in the district. The workshop discussed various initiatives that women would take forward in order to overcome the cultural barriers that have hindered them from taking active roles (Saferworld, 2010).

USAID/PACT International through the Kenya Civil Society Strengthening Program (KCSSP) PACT supports the work of local CSOs working on peace building and advocacy. Kewap-Ng'etuny women group was one of the women initiatives at peace-building initiated to address the boundary disputes in Kaimugul sub-location in Kopsiro division. The intervention was centered on resolving the boundary disputes through non-violent approaches of using the Sigowet thorny shrub to solve the land boundary disputes through fencing to reduce land conflicts. It also envisioned awareness creation on electoral process through voter education in the region to reduce the propensity to political incitement given that politics has frequently been cited as a trigger to the Mt. Elgon conflict (Simiyu, 2008; HRW, 2008). The initiative has had some drawbacks since the Ministry of Lands has not clearly demarcated the land in Kopsiro division and this will greatly hinder peace in the region given that the root cause of the conflict in the region was land. In all the efforts above, the effect of ICTs on peace building was not explored.

\subsection{ICTs in peace-building}

ICTs have permeated almost every aspect of human life in the current information age. In order to investigate ICTs effectiveness in transforming violent situations into peaceful coexistence and to establish ICT tools that could be used to provide reconciliation, researchers sought to establish the extent of use of ICTs in alleviating these conflicts. For instance, social networking is fundamental in reintegrating ex-combatants into civilian life (Cilliers, \& Schuenemann, 2013). Ex-combatants also use their personal social networks for other means such as finding work or potential investors and sourcing credit. In Africa, social networking is usually conducted via telephone, text messaging and face-to-face interaction (Cilliers, \& Schuenemann, 2013). Hattotuwa (2004), in his study in South Asia, observed that peace-building processes could be greatly strengthened by social networks. This is because people are connected in multi-sectoral and peace-building networks, and are provided with active and open knowledge bases. Thus, they get instant access to effective peace building approaches and at times case studies. Successful conflict transformation does not come in the form of technology per se, but in the ability of societies to organically develop their social capital to develop non-violent creative ways of addressing inequality, exclusion and legitimate grievances (Hattotuwa, 2004).

According to Cole and Crawford (2007), ICTs can be of tremendous help in implementing peace-building initiatives. For instance, in the Philippines, large scale demonstrations organized via cell phones and SMS (short text messages) were a major factor in forcing President Joseph Estrada to resign, thus bringing about change without largescale violence. The United States Army has been piloting a hand held system that contains maps and descriptions of civilian and militia inhabitants to help them gain a deeper understanding of the communities in which they are serving as peacekeepers (Cole \& Crawford, 2007). These hand-held human terrain tools are also being put to use by humanitarian relief organizations (Cole \& Crawford, 2007). During the conflicts in Burundi, online discussion groups hosted by Burundinet and the Burundi Youth Council allowed Burundi people of different backgrounds to discuss the situation, debate root causes, and figure out ways to move forward, without meeting physically. The service Videoletters.net captures video messages and broadcasts them via public access channels throughout the countries of the former Yugoslavia, thus allowing those who lost contact in the wars to reconnect (Cole \& Crawford, 2007). Likewise, the use of Online Dispute Resolution (ODR) for peace-building and conflict transformation, and its ability to support nascent peace processes through virtual single-text or one text negotiations, has been promoted in Sri Lanka conflicts with positive results (Hattotuwa, 2004). This has potential success in refugee and internally displaced persons resettlement, disaster relief management, conflict prevention and early warning, resource based conflicts, support operations and help in other ethnic protracted conflicts. One of the respondents remarked:

\footnotetext{
"...It would be of great help for the majority, if not all of the residents to have mobile telephones loaded with airtime...this can help in cases of emergencies and many lives could be saved since information would be shared instantaneously. The natives should also be equipped with solar battery chargers for the cell phones so that they can be charged all the times...at times, information cannot be passed across quickly because the batteries run down and cannot be charged immediately because of lack of electricity..."
} 
There was concurrence on these views by all the respondents. It is therefore observable that even though there have been sporadic attempts to use ICTs in peace building, Mt. Elgon area has not benefited much. During the interviews, it was observed that many of the respondents used traditional methods of communication. Less than $20 \%$ used at least one form of ICTs. This had negative implications in peace-building efforts. For instance, majority of them arrived late for meetings, response in real-time was inhibited and they were cut out from local, regional and global forums.

\section{Proposed Framework for Peace-Building}

In line with the objectives of this study, a framework for peace-building in Mt. Elgon has been proposed. A comprehensive approach to peace-building involves engaging a variety of actors. One of these includes a Multi-Track Diplomacy (MTD) which is a conceptual way to view the process of international peacemaking as a living system (McDonald, 2012). It looks at the web of interconnected activities, individuals, institutions, and communities that operate together for a common goal: a world at peace. For instance, track one is the level of official diplomacy at which conflicts are resolved, ceasefires agreed upon and peace accords signed (McDonald, 2012). The third parties can engage in brokering and mediation as Norway did in Sri Lanka (GTZ, 2004). One of the strengths of the state actors is that it is endowed with power occasioned by constitutional sovereignty which allows it to use state resources (Abdulrahman \& Tar, 2008; UNDP, 2009). However, track one diplomacy is set with bureaucratic problems because people at the grassroots level do not own it. This has been the reason for the failure by many external interventions in conflict as witnessed in UN mediation in Rwanda, Cyprus and Somalia (Nyong'0, 2000). Track two refers to a range of unofficial contacts and interactions between and within states including the civil society, NGOs, media, academia, businesses, experts and CBOs (Abdulrahman \& Tar, 2008; UNDP, 2009). However, there is often reluctance by the state to accept the input of the NGOs. Multi-track diplomacy include 3-8 tracks as an all-inclusive approach to peace-building that utilizes systems-based approach by recognizing that the transformation of deep-rooted conflicts cannot be left solely to governmental entities, but must include non-governmental actors, civil society and other informal channels (McDonald, 2012) (Figure 1).

Figure 1: Multi-Track Diplomacy

Source: McDonald (2012)

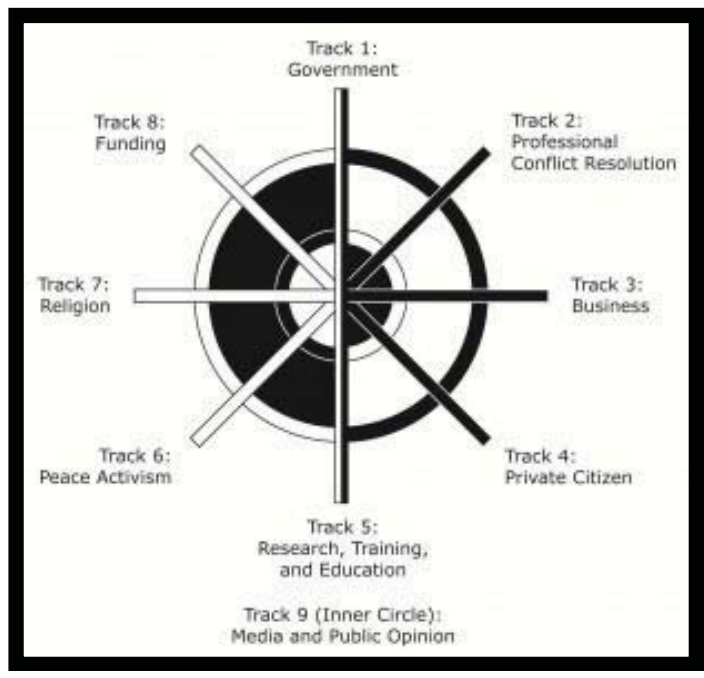

In summary, the study proposes the following needs in order to realize peace in Mt. Elgon region:

- The Ministry of Lands and Settlement to adequately assess, demarcate the land and speed up the issuance of land title deeds to the owners of the Chebyuk settlement scheme; 
- Disarmament of the community members should be conducted since many small arms and light weapons (SALWs) are still in the hands of the civilians;

- There is need to closely monitor the Kenya-Uganda border at Malaba, Chepkube and Suam borders to avoid the infiltration of SALWs in the region;

- Conducting trauma healing in schools and other institutions especially for orphans;

- Establishing orphans and children's homes in the region due to the large number of orphans and vulnerable children;

- The state actors to work in collaboration with the non-state actors in peace-building initiatives in the region;

- The potential of ICTs such as the internet, cellular telephones and radio phones in peace-building to be explored.

\section{Conclusion}

The purpose of this study was to investigate the role of governmental, non-governmental organizations and the potential role of ICTs in peace-building. The paper examined the on-going peace-building efforts in Mt. Elgon region following the government's failed attempts to resettle the landless members of the Sabaot community in Chebyuk settlement scheme. The crisis led to the formation of the dreaded militia group-SLDF which unleashed terror on the residents. In an attempt to deal with the menace, the state deployed the military who were accused of human rights abuses against the civilians. Efforts at peace-building and reconciliation initiated by the state, international NGOs, national NGOs, the CSOs, CBOs and FBOs are on-going. Empirical data on conflict transformation following the land conflict in Mt. Elgon may make the realization of a peaceful Mt. Elgon region elusive. Several peace-building efforts by the government and nongovernmental players have not been successful in achieving a long lasting peaceful solution to the conflict. Preliminary results from this study indicate that there is need to investigate the effectiveness of ICTs as an alternative means in peace-building in the region. Such an effort is likely to yield fruits in order to avoid a relapse into violence and this needs further study.

\section{References}

Abdulrahman, I. \& Tar, U. (2008). Conflict Management and Peace-building in Africa: The Role of State and Non-state Agencies. Information, Science \& Justice, 1(2), 185-202.

Anyu, J. (2007). The International Court of Justice and Border-Conflict Resolutions in Africa: The Bakassi Peninsula Conflict. Mediterranean Quarterly, 18(3), 40-55.

Babaud, S. \& Ndung'u, J. (2012). Early Warning and Conflict Prevention by the EU: Learning Lessons from the 2008 Post-Election Violence in Kenya. Initiative for Peace Building - Early Warning Analysis to Action (IfP-EW).

Baumann, J. (2011). The Mount Elgon Conflict in Kenya Uppsala Conflict Data Program: UCDP Conflict Encyclopedia: Uppsala University. Department of Peace and Conflict Research.

Berghof Foundation. (2012). Berghof Glossary on Conflict Transformation: 20 Notions For Theory and Practice. Berghof Foundation: Berlin.

Boaduo, N. (2010). Epistemological Analysis: Conflict and Resolution in Africa. The Journal of the Pan African Studies, 3(10), 168-179.

Bryan, A. \& Burgress, R. (1999). Qualitative Research. London: Sage.

Cheldelin, S., Druckman, D. \& Fast, L. (2003). Conflict: From Analysis to Intervention. London: Continuum.

Cilliers, J. \& Schuenemann, J. (2013). The Future of Intrastate Conflict in Africa: More Violence or Greater Peace? Institute for Security Studies, Pretoria.

Cole, R. \& Crawford, T. (2007). Building Peace Through Information and Communications Technologies. In http://www. dealware.org/ articles/building-peace-through-information-and-communications-technologies. Accessed on 29/09/2013.

Comninos, A. (2013). The Role of Social Media and User- Generated Content in Post-Conflict Peace-Building. Paper Presented at the Conference: History and Experience of Post-conflict Reintegration and Stabilization Reflections from DDR in Africa, June 5-6, 2013, Tunis, Tunisia.

Cresswell, J. W. (2007). Qualitative Inquiry \& Research Design: Choosing Among Five Approaches (2nd Ed.). US: Sage Publications.

Dearing, J. W. (2010). Applying Diffusion of Innovation Theory to Intervention Development. Research in Social Work Practice. 19(5), 503-518.

Fati, O. I. (2010). Impact of Information and Communication Technology on Conflict Management: The Nigerian Niger-Delta Conflict in Perspective, Staff Papers, University of Jos, 2010. Available online at: http://cisweb1.unijos.edu.ng/handle/ 10485/1113.

Greenhalgh, T., Robert, G., Macfarlane, F., Bate, P. \& Kyriakidou, O. (2004). Diffusion of Innovations in Service Organizations: Systematic Review and Recommendations. Milbank Quarterly. 82(4), 581-629.

GoK. (2012). A Validated Report of the National Conflict Mapping and Analysis With Recommendations for Actors. NPI-Africa and the 
NSC Secretariat: Nairobi

GTZ. (2004). Peace-Building, Crisis Prevention and Conflict Management: Technical Cooperation in the Context of Crises, Conflicts and Disasters. State and Economic Reform, Civil Society, Division 42, Eschborn: Germany.

Hattotuwa, S. (2004). Mediation from the Palm of Your Hand: Forging the Next Generation Odr Systems. Dialogue, 2(2), 39-68.

Human Rights Watch (HRW). (2008). Kenya: Army and Rebel Militia Commit War Crimes in Mt. Elgon. Available at http://www.reliefweb.int/rw/rwb.nsf/db900sid/ASAZ-7DDCD5? Open document [Accessed 20 April 2013].

Islam, R. \& Chakma, A. (2013). Major Obstacles to the Process of Implementing Peace: Experience from Chittagong Hill Tracts (CHT) in Bangladesh. Peace and Conflict Review, 7(2), 29-46.

Kaminski, J. (2011). Theory in Nursing Informatics Column. Canadian Journal of Nursing Informatics. 8(3), 1.

Kamoet, A. (2007). A Historical Overview of Mt. Elgon Crisis: Proceedings of the Mt. Elgon Crisis Workshop Held At Masinde Muliro University Of Science And Technology, Kakamega, Kenya From 28 to 29 June, 2007.

KNCHR. (2008). Kenya National Commission on Human Rights: On the Brink of The Precipice: A Human rights Account Of Kenya's Post-2007 Election Violence Final Report, 15 August 2008.

McDonald, J. W. (2012). "The Institute for Multi-Track Diplomacy" [online profile]. Journal of Conflictology. 3(2), 66-70.

McGill-Frazen, A. \& Allington, R. (eds.). (2011). Handbook of Reading Disability Research. New York: Routledge.

Moore, J. (2011). Truth Commissions: Can Countries Heal After Atrocities? In Issues in Peace and Conflict Studies: Selections from CQ Researcher. Sage Publications Inc.

Mwasserah, A. (2008). An Overview of the Causes of the Mt. Elgon Crisis and Its Effects on the Province and Possible Solutions. Paper Presented At Mt. Elgon Crisis Workshop Held at Masinde Muliro University of Science and Technology, Kakamega, Kenya from 28 to 29 June, 2008.

Nyong'0, P. (2000). Governance, Security and Conflict Resolution in Africa. Diagones. 46(4), 129-139.

Okoth, G. \& Ogot, B. (eds.) (2009). Conflicts in Contemporary Africa (20-29). Jomo Kenyatta Foundation: Nairobi, Saferworld Activity Report, December 2008-January 2009.

Quinn, D., Wilkenfeld, J., Eralp, P., Asal, V. \& Mclauchlin, T. (2013). Africa Crisis Managers But Not Conflict Resolvers: Mediating Ethnic Intrastate Conflict In Africa. DOI: 10.1177/0738894213491352.

Rogers, E. M. (2003). Diffusion of Innovations. (5th ed.). New York: Free Press.

Rogers, E. M. (1995). Diffusion of Innovations (4th ed.). New York: Free Press.

Saferworld. (2010). Saferworld: IASZNU: Opportunities for International Action On Sudan: Two Views. China.

Simiyu, R. (2008). Militianisation of Resource Conflicts, Monograph 152. Institute of Security Studies.

UNDP. (2009). Training Resource Guide on Conflict Prevention and Transformation: National Steering Committee on Peace-building and Conflict management.

Uzuegbunam, A. O. (2013). Non-Governmental Organizations (NGOs) Conflict and Peace Building in Nigeria. Open Journal of Philosophy, 3(1A), 207-212.

Wanda, E. (2013). Briefing Report on First Dialogue: Widowhood Crossing Cultural - Spiritual Borders for Restorative Peace in the Mt. Elgon Area Held on 1 ${ }^{\text {st }}$ May, 2013 at Africa Study Centre: Mbale, Uganda.

Welling, J. J. (2007). Non-governmental Organizations, Prevention, and Intervention in Internal Conflicts: Though the Lens of Darfur. Indiana Journal of Global Legal Studies, 14(1), 8.

Wilson, J. \& Wilson, H. (2009). Digital Divide: Impediment to ICT and Peace Building in Developing Countries. American Communication Journal, 11(2), 1-9. 